\title{
Weronika Kostecka*
}

\section{Dziwne - odmienne - obce. Dziecko jako Inny we współczesnej polskiej prozie dziecięcej i młodzieżowej}

DOI: http://dx.doi.org/10.12775/LC.2017.052

Streszczenie: Przedmiotem artykułu jest analiza literackich obrazów dziecka jako Innego w utworach reprezentujących współczesną polską prozę dziecięcą i młodzieżową. Rozważania obejmują kilka wybranych aspektów „inności”, przede wszystkim: (1) odmienność wynikającą z niepełnosprawności fizycznej (m.in. powieści Barbary Ciwoniuk, Ireny Landau, Ewy Nowak); (2) odmienność będącą rezultatem niepełnosprawności intelektualnej (m.in. utwory Katarzyny Ryrych, Beaty Wróblewskiej) oraz (3) odmienność narodową (powieści autorstwa Grzegorza Gortata i Ewy Grętkiewicz). Problemy badawcze dotyczą tego, w jaki sposób polscy autorzy prezentują pojęcia inności i obcości, jak obrazują Innego, jak przedstawiają relacje między nim a jego otoczeniem rodzinnym i - szerzej - społecznym, jakie dylematy tożsamościowe oraz problemy związane z innością i postawami wobec niej wskazują.

Słowa kluczowe: Inny, obcy, inność, obcość, odmienność, dziecko jako Inny

\footnotetext{
* Doktor nauk humanistycznych w zakresie literaturoznawstwa, pracownik Zakładu Literatury Popularnej, Dziecięcej i Młodzieżowej Wydziału Polonistyki na Uniwersytecie Warszawskim. Jej zainteresowania badawcze obejmują historię oraz teorię literatury dziecięcej i młodzieżowej. E-mail: w.kostecka@uw.edu.pl.
} 


\title{
Strange - different - foreign. The child as the Other in contemporary Polish prose for children and youth
}

\begin{abstract}
The aim of this article is to examine images of the child perceived as the Other that appear in contemporary Polish children's and young adult literature. The analysis focus on the following aspects of "otherness": (1) physical disability and its results (in the novels of Barbara Ciwoniuk, Irena Landau, Ewa Nowak); (2) intellectual disability and its results (in the works of Katarzyna Ryrych, Beata Wróblewska); and (3) national belonging (in the works of Grzegorz Gortat and Ewa Grętkiewicz). The key research questions concern the literary strategies applied by Polish authors to present strangeness, the Other, as well as the relations between the latter and his or her social environment. Moreover, the author analyses the literary visions of identity dilemma and the diverse attitudes to otherness that are reflected in the works discussed.
\end{abstract}

Keywords: the Other, the alien, otherness, strangeness, the child as the Other

ategoria „inności” może być rozpatrywana na co najmniej kilka różnych sposobów: w perspektywie antropologicznej - gdy przedmiotem namysłu stają się takie pojęcia, jak swojskość czy obcość, socjologicznej - skupionej na procesie społecznego „konstruowania” tożsamości jednostki i całych grup, kulturoznawczej - której reprezentanci badają stosunek kultury „dominującej” do „obcej”, czy wreszcie w perspektywie psychologicznej, gdy analizie podlega poczucie obcości, inności podmiotu wobec siebie samego ${ }^{1}$. „Inność” konotuje „dziwność”, ta zaś wyzwala najrozmaitsze reakcje - od prób unicestwienia Innego, poprzez próby unicestwienia inności², aż po próby koegzystencji. Przedmiotem tego artykułu będzie analiza literackich obrazów dziecka jako Innego w utworach reprezentujących wspólczesną polską prozę dziecięcą i młodzieżową.

1 Zob. M. Dąbrowski, Swój / obcy / inny. Kontynuacja „Anthropos?” 2009, nr 12/13, http://www.anthropos.us. edu.pl/anthropos7/texty/dabrowski.htm (dostęp: 22.10.2015).

2 Na temat dwóch pierwszych strategii zob.: Z. Bauman, Płynna nowoczesność, przeł. T. Kunz, Kraków 2006, s. 157; Bauman opiera się w swoich rozważaniach na konstatacjach Claude'a Lévi-Straussa zawartych w Smutku tropików. 


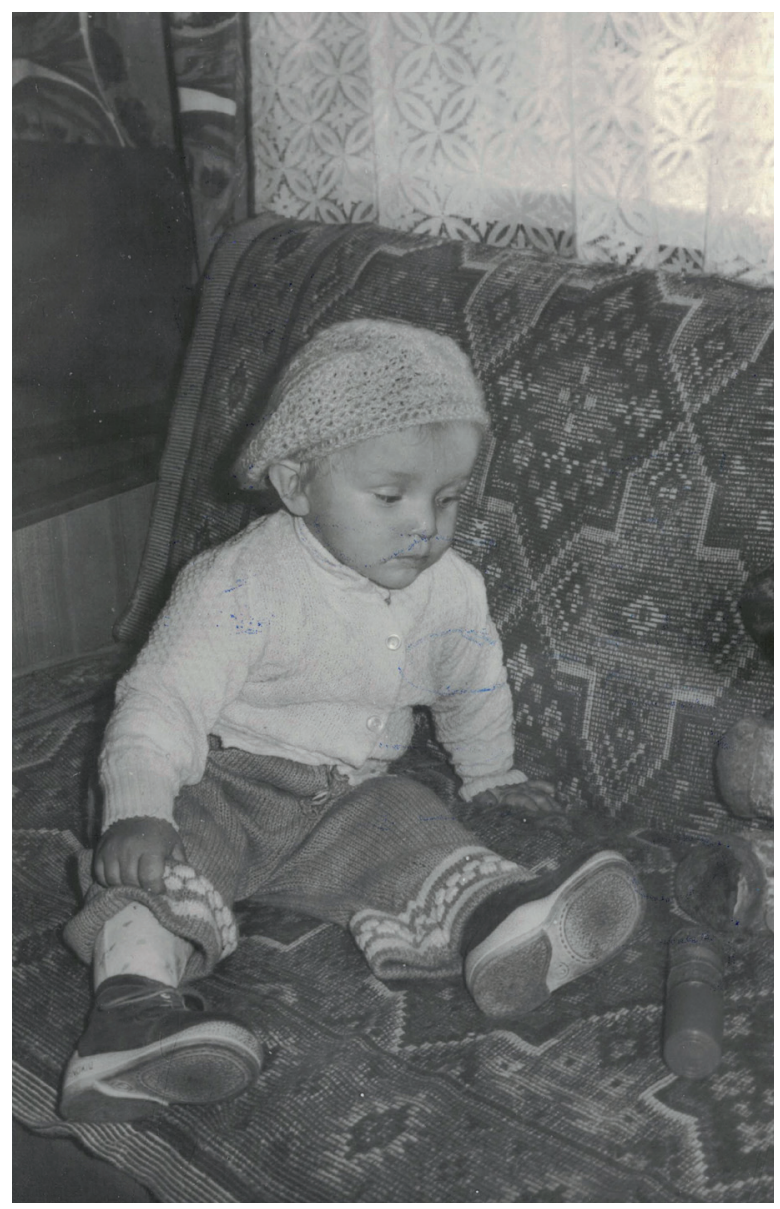

Chłopiec i zabawki, lata 80. XX wieku. Z archiwum redaktorów naukowych tomu.

Jolanta Sztachelska, analizując kategorię „dziwności dziecka jako jedynego podmiotu, który nie jest w stanie ani sam o sobie mówić, ani o sobie stanowić, ani poznać samego siebie [... ]”3, przywołuje następujące wymiary kulturowego obrazu dziecka: „kategorie wiekowe” (niedająca się uchwycić różnica między „dziecięctwem i adolescencją czy dorosłością”), „dzikość dziecka” („,cecha o proweniencji russoistycznej, akcentująca niejasne pochodzenie dziecka, dziwne zachowanie, amoralizm, aspołeczność”), „nieokreśloność roli społecznej”, „niemota” („,echa dotycząca rzeczywistego braku głosu [...], odmienność języka dzieci i dorosłych [...]”), „wyobraźnia, wrażliwość, emocjonalizm”, wreszcie - „cielesność, płciowość” („Dziecko [...] znajduje się pomiędzy porządkiem męskim i kobiecym [...]”) W kontekście tak rozumianej dziwności dziecka jako kulturowej wizji konstruowanej przez

3 J. Sztachelska, „Dziwność” dziecka. Rzecz o imaginarium społecznym, [w:] Children studies jako perspektywa interpretacyjna. Studia i szkice, red. J. Sztachelska, K. Szymborska, Białystok 2014, s. 52; wyróżnienie oryginalne.

4 Ibidem, s. 51-52. Por. uwagę Małgorzaty Chrobak: „W minionym stuleciu ukształtował się osobny paradygmat studiów nad dzieciństwem, rozwijający tezę Janusza Korczaka z manifestu Prawo dziecka do szacunku, że w świecie dorosłych dziecku przypadło miejsce »cudzoziemca«, kogoś, kto doświadcza obcości. Najmłodsi nie rozumieją języka, gestów ani praw, jakie narzuca dorosła większość"; M. Chrobak, Ucząc się od Jurgielewiczowej. 
dorosłych dziwność niedorosłych bohaterów utworów analizowanych w tym artykule wypada uznać za „podwójną”, „spotęgowaną”. Będzie to bowiem dziwność konotowana przez inność wynikającą z konfrontacji już nie tylko kulturowych konstruktów dziecięctwa i dorosłości, lecz przede wszystkim pojęcia „normy” funkcjonującego w społeczeństwie z tym, co od tej „normy” odbiega; co więcej, w wielu powieściowych przypadkach ta konfrontacja będzie przebiegać na linii dziecko-dziecko. Rozważania obejmą kilka wybranych aspektów „inności”, przede wszystkim: odmienność wynikającą z niepełnosprawności fizycznej, odmienność będącą rezultatem niepełnosprawności intelektualnej oraz odmienność narodową.

Osobnych rozważań wymagałyby literackie obrazy odmienności wyznania, portrety bohaterów nieheteronormatywnych czy też kwestionujących tradycyjny podział ról społecznych - „męskich” i „kobiecych”; jednakże ze względu na ograniczone rozmiary tego szkicu należało wybrać jedynie kilka aspektów inności spośród wielu istniejących. Z kolei zestawianie $\mathrm{w}$ analizie literackich obrazów inności kwestii związanych z niepełnosprawnością fizyczną i intelektualną z tymi dotyczącymi odmienności narodowej może się wydawać kontrowersyjne ze względu na nietożsame zjawiska (natury m.in. psychologicznej i socjologicznej) towarzyszące percepcji tych różnych „typów” odmienności (postrzeganiu ich, rozmaitym reakcjom, definiowaniu „normy” i odstępstw od niej itd.). Za „wspólny mianownik" rozważanych tu wymiarów odmienności zostanie jednak uznane zjawisko stygmatyzacji, które pojawia się wtedy, gdy wrażeniu inności (choćby i niewyartykułowanemu bezpośrednio) towarzyszy odczucie obcości. Jak zauważa Małgorzata Chrobak: „Obcość związana jest zwykle z Innością, choć częściej, w przeciwieństwie do tej drugiej, prowokuje negatywne asocjacje”. Na tę zależność zwracała nieco wcześniej uwagę Hanna Gosk: „Takie przypadki, w których inność łączy się z obcością, potocznie nabierają nacechowania negatywnego. Inny, jawiący się jako nieznany, a więc często niezrozumiały, może wydawać się groźny"6. Rozważania będą zatem dotyczyć inności nierozumianej, konotującej pejoratywnie nacechowaną dziwność, nieraz także obcość, i wyzwalającej reakcje będące świadectwem czy to chybionych prób zrozumienia Innego, czy to niechęci wobec podjęcia takich prób, czy wręcz jawnie okazywanej wrogości.

W eseju zamieszczonym w zbiorze Ten Inny Ryszard Kapuściński wskazuje na socjologicznie rozumiany dualizm człowieka:

Inna w powieści Katarzyny Pranič „Ela-Sanela”, [w:] Wyczytać świat - międzykulturowość w literaturze dla dzieci i młodzieży, red. B. Niesporek-Szamburska, M. Wójcik-Dudek, A. Zok-Smoła, Katowice 2014, s. 84.

5 M. Chrobak, Obcość jako kategoria interpretacyjna w badaniach nad dzieciństwem i literatura dla dzieci, [w:] Children studies jako perspektywa interpretacyjna, s. 60.

${ }^{6}$ H. Gosk, Bohater literacki o cechach Innego/Obcego, w: eadem, Bohater swoich czasów. Postać literacka w powojennej prozie polskiej o tematyce współczesnej. Wybrane zagadnienia, Izabelin 2002, s. 65. W artykule autorka m.in. analizuje i wyjaśnia charakter relacji między pojęciami inności i obcości. Analizę zakresów semantycznych wymienionych pojęć przeprowadzoną z perspektywy filozoficznej można z kolei znaleźć w: H. Gruchlik, Inność a obcość w kontekście filozoficznym, „Anthropos?” 2007, nr 8/9, http://www.anthropos.us.edu. pl/anthropos5/ texty/gruchlik.htm (dostęp: 22.10.2015). Por. także uwagę Małgorzaty Chrobak: „[...] zazwyczaj definiuje się ją [inność - W. K.] wspólnie z obcością, choć w przeciwieństwie do tej drugiej - ma nacechowanie dodatnie bądź obojętne. Tymczasem Obcego potocznie kojarzymy z wrogiem, z zagrożeniem (vide obce cywilizacje z kosmosu), do czego walnie przyczyniło się stopniowe przesunięcie na gruncie ludowym z przestrzeni akceptowanego do przestrzeni odrzuconego. Odium negatywnego stereotypu przypieczętowało złą sławę gatunku Obcych w kulturze współczesnej. Stawia się ich w opozycji do »swoich«, »naszych«, czyli znanych"; M. Chrobak, Ucząc się od Jurgielewiczowej, s. 83. 
Każdy z tych ludzi spotykanych w drodze przez świat składa się jakby z dwóch istot, jest dwoistością, którą często trudno rozdzielić, z czego zresztą nie zawsze zdajemy sobie sprawę. Jedna z tych istot to człowiek jak każdy z nas; ma swoje radości i smutki, swoje dobre i złe dni, cieszy się z sukcesów, nie lubi być głodny, nie lubi, kiedy jest mu zimno, odczuwa ból jako cierpienie i nieszczęście, odczuwa pomyślność jako satysfakcję i spełnienie. Druga istota, nakładająca się i spleciona z pierwszą, to człowiek jako nosiciel cech rasowych, nosiciel kultury, wierzeń i przekonań. Żadna z tych istot nie występuje w stanie czystym i wyizolowanym, obie współżyją ze sobą, wzajemnie na siebie oddziałując

Inny, czy wręcz: Obcy, nie jest zatem jedynie czarnoskórym przybyszem z odległego kraju, nie jest „po prostu” Żydem czy Azjatą. Człowieczeństwo Innego nie daje się zredukować do faktu, że porusza się on na wózku, jego wygląd lub sposób zachowywania się jest „niestandardowy” lub - mimo dojrzałego wieku - człowiek ów ma umysł kilkuletniego dziecka. Chęć zaklasyfikowania zaobserwowanej odmienności jako obcości, a w związku z tym skłonność do prostego kategoryzowania i etykietowania, wynika, być może, z przedkładania - choćby nieuświadomionego - tego, co Anthony Giddens określa jako tożsamość s połeczną (warunkującą przynależność człowieka do danej grupy, a więc jego podobieństwo do pozostałych jej członków - spełnianie określonej „normy”), nad t o ż s m o ść je d n o st k o wą. Wspomniany badacz wyjaśnia to następująco:

Tożsamość społeczna dotyczy cech, jakie jednostce przypisują inni. Cechy te można rozumieć jako wyznaczniki tego, kim zasadniczo j e st ta osoba. Jednocześnie określają one stosunek jednostki do innych jednostek posiadających takie same cechy. Przykłady tożsamości społecznych to student, matka, prawnik, katolik, bezdomny, Azjata, dyslektyk, żonaty itd. [...] tożsamości społeczne mają wymiar zbiorowy. Są znakiem tego, że jednostki są „takie jak inni”.

Podczas gdy tożsamości społeczne określają, w czym jesteśmy tacy jak inni, tożsamość jednostkowa (czyli tożsamość osobista) zaznacza naszą odrębność względem innych. Tożsamość jednostkowa dotyczy procesów samorozwoju, w których wykształca się nasze wyjątkowe poczucie bycia sobą i niepowtarzalny stosunek do otaczającego świata. [...] Środowisko kulturowe i społeczne jest czynnikiem kształtującym naszą tożsamość, ale centralne znaczenie ma jednostkowe działanie i dokonywanie wyborów ${ }^{8}$.

„[... ] każde spotkanie z Innym - by przywołać raz jeszcze Kapuścińskiego - jest zagadką, jest niewiadomą, jest - powiem więcej - tajemnicą"9 Pojęcie tajemnicy należałoby więc uznać za kluczowe dla analizowanego tu obszaru problemowego. Może ona bowiem, z jednej strony, ciekawić, intrygować, fascynować, zachęcać do rozważań nad kategorią „swoj(sk)ości/obcości, zamkniętości/otwartości itp., czemu towarzyszyć musi refleksja nad kategorią granicy, przejścia, transgresji, tabu etc." ${ }^{10}$; z drugiej zaś - budzić niepokój, obawy, lęk, naruszać poczucie bezpieczeństwa i w związku z tym napełniać niechęcią. Trudny wybór strategii mówienia o inności - strategii „przezroczystej” (o ile to możliwe) lub zaangażowanej ideowo - i zaaranżowanie spotkania niedorosłego czytelnika z Innym stanowią zatem jedno z istotnych wyzwań cywilizacyjnych, jakie stoją przed współczesną

\footnotetext{
7 R. Kapuściński, Wykłady wiedeńskie I, [w:] idem, Ten Inny, Kraków 2006, s. 10.

8 A. Giddens, Socjologia, przeł. A. Szulżycka, Warszawa 2004, s. 52.

9 R. Kapuściński, Wykłady wiedeńskie I, s. 11.

10 M. Dąbrowski, op. cit.
} 
literaturą dziecięcą i młodzieżową. Wziąwszy pod uwagę dopiero rozwijające się w Polsce debaty społeczne na temat różnego rodzaju odmienności, można postawić tezę, że w przypadku literatury rodzimej waga tego wyzwania jest szczególna.

We wstępie do Wyspy mojej siostry - opowieści przedstawiającej perypetie dziewczyny z zespołem Downa i jej rodziny - nagrodzonej w konkursie literackim im. Astrid Lindgren, Katarzyna Ryrych wyraża następującą obawę: „Nie wiem, jak o tym opowiedzieć, żeby wszyscy, którzy boją się przybijać do brzegów nieznanych wysp, uwierzyli, że nie ma na nich ludożerców, dzikusów ani potworów - tylko ludzie"11. W jaki sposób wytyczane są zatem szlaki do owych nieznanych wysp, jak prezentują się literackie próby doprowadzenia do tego, by wyspa Innego i ląd zamieszkiwany przez „swoich” zbliżyły się do siebie? Co wynika ze spotkania z Innym, a w szczególności - z dzieckiem-Innym? Co się dzieje, gdy wyspa inności staje się moją w $\mathrm{l}$ a s ną wyspą?

Paradoksalnie łatwiej jest wskazać Innego, dostrzec i opisać jego odmienność, niż określić, kim jestem ja s a m. Jak wskazuje Giddens, „do najważniejszych źródeł tożsamości należą płeć, orientacja seksualna, narodowość lub etniczność i klasa społeczna” ${ }^{12}$. Jednocześnie to właśnie m.in. te elementy prowokują wręcz do prostej - jak starają się pokazać twórcy dla dzieci i młodzieży: zbyt prostej - kategoryzacji: „rusek”, „czarny” itd., a obok tego - „kaleka”, „wariat”, „down”; przykłady można by mnożyć. Tego typu głęboko zakorzenione w myśleniu, stygmatyzujące stereotypy, kojarzące się z „dziwnością”, „nienormalnością” i - nieraz bezwiednie - wykorzystywane w konstruowaniu „swojej” rzeczywistości i jej opisu, sprawiają, że napotkany człowiek zostaje wykluczony z grona „swoich” i zaklasyfikowany jako ktoś, kto nie pasuje: jako Inny.

„Słowo tożsamość oznacza świadomość siebie - wyjaśnia Małgorzata Budyta-Budzyńska - zdolność określenia, kim się jest, do jakiej grupy się należy, z jaką grupą człowiek się identyfikuje i do jakiej się przyznaje. Jest to rodzaj samowiedzy dotyczącej tego, co dla jednostki jest najważniejsze, najbardziej charakterystyczne, co ją tworzy, jest jej »istotą "13. Tymczasem owa samowiedza niepokojąco często zdaje się rozwijać w opozycji do tego, co inne, a więc postrzegane jako dziwaczne i nieakceptowane. Nie tyle zatem „jestem biały”, ile „nie jestem czarny”; nie tyle dbam o wzorcowe posługiwanie się ojczystym językiem, ile nie kaleczę go jak przybysz z innego kraju; nie tyle zdolny jestem poznawać świat, przemierzając go dzięki dwóm sprawnym nogom, oglądać go dzięki dwojgu sprawnych oczu i rozumieć dzięki sprawnemu umysłowi, ile nie jestem „kaleką” ani „wariatem”.

11 K. Ryrych, Wyspa mojej siostry, Warszawa 2011, s. 7

12 A. Giddens, op. cit., s. 51.

13 M. Budyta-Budzyńska, Socjologia narodu i konfliktów etnicznych, Warszawa 2010, s. 91. 


\section{Inny-niepełnosprawny: odmienność fizyczna ${ }^{14}$}

Polscy twórcy literatury dziecięcej i młodzieżowej coraz częściej sięgają po tematy dotyczące różnych odmian inności i obcości, ukazując różnorodne aspekty spotkania z Innym. Najbardziej oswojony i - by tak rzec - płodny literacko wydaje się problem niepełnosprawności fizycznej. Bohaterowie poruszający się na wózkach inwalidzkich są częstymi postaciami polskiego pejzażu powieściowego. Barbara Ciwoniuk w Tym grubym ${ }^{15}$ przedstawia m.in. historię dziewczyny, która, zrozpaczona utratą sprawności i przykuciem do wózka, odmawia opuszczania domu i buntuje się przeciw konieczności rehabilitacji, ponieważ nie wierzy już w jej sens. Irena Landau opowiada o trudnym procesie oswajania się z nową sytuacją - bohaterka powieści Uszy do góry! ${ }^{16} \mathrm{w}$ wyniku wypadku traci władzę w nogach i zmuszona jest na nowo poznawać świat z perspektywy wózka inwalidzkiego. Musi zmierzyć się z własnymi uczuciami - złością, strachem i zniechęceniem, a także z emocjami najbliższych, którzy pod maską optymizmu, beztroski i dobrego humoru ukrywają przerażenie i bezradność wobec cierpienia. Inność, zwłaszcza taka, która rodzi się nagle i niespodziewanie, stawia bliskich cierpiącej osoby przed koniecznością wyboru postawy wobec tej inności. Autorka konfrontuje zachowanie rodziców bohaterki, którzy za wszelką cenę zapewniają dziewczynkę o „tymczasowości” jej stanu i starają się unikać jakichkolwiek niezręczności (także językowych - na przykład sformułowań związanych z chodzeniem, wstawaniem itp.), które w ich mniemaniu mogłyby ją urazić, z podejściem jej starszego brata. Ten ostatni nie zamierza ograniczać ani cenzurować dotychczasowych żartów z siostry - dając jej tym samym do zrozumienia, że traktuje ją tak samo jak przed wypadkiem.

Mama nie znosi tego słowa [„kaleka” - przyp. W. K.]. „Nie jesteś kaleką - denerwuje się - tylko po prostu nie chodzisz. Jesteś, no, czasowo niepełnosprawna"17.

Niepotrzebnie się denerwował [ojciec bohaterki - przyp. W. K.], Artur zawsze mi dokuczał i nie widzę powodu, żeby miał przestać tylko dlatego, że siedzę, zamiast chodzić.

- Ale tato - mówię - daj spokój, Artur żartuje.

- Idiotyczne żarty!

Wcale nie. Mam dosyć cackania się, tych sztucznych rozmówek. Zupełnie, jakby rozmawiali z debilką, tacy wszyscy radośni, tak mnie kochają i tak bez przerwy o tym mówią. Po co? I bez zapewnień wiem, że rodzice nie przestali mnie kochać dlatego, że nie mogę chodzić ${ }^{18}$.

Z głęboko skrywaną rozpaczą nie potrafią sobie poradzić niepełnosprawna bohaterka i jej matka ze wspomnianej już powieści Ciwoniuk, raniąc się nawzajem w nieszczerych

\footnotetext{
14 Poniższe rozważania zawierają przeredagowane fragmenty publikacji: W. Kostecka, Niepokojaca odmienność. Trudne tematy we współczesnej polskiej prozie dla młodzieży na wybranych przykładach, „Świat Książki Dziecięcej” - dodatek do „Poradnika Bibliotekarza” 2013, nr 3, s. 1-4.

15 Zob. B. Ciwoniuk, Ten gruby, Kraków 2011.

16 Zob. I. Landau, Uszy do góry!, Łódź 2011.

17 Ibidem, s. 6.

18 Ibidem, s. 8.
} 
rozmowach, w których żadna z nich nie potrafi powiedzieć otwarcie o swoich uczuciach. Z kolei Ewa Nowak przedstawia w Danych wrażliwych ${ }^{19}$ - w ramach drugoplanowego wąt$\mathrm{ku}$ - przejmującą historię dziewczyny poruszającej się na wózku, która została całkowicie ubezwłasnowolniona przed rodzinę; ponieważ z racji swej niepełnosprawności uzależniona jest od innych osób, traktuje się ją jak dziecko.

Z kwestią niepełnosprawności jako inności wiąże się problem tabu; czy o własnej lub cudzej odmienności należy w ogóle mówić, czy należy ją zauważać, jak się do niej ustosunkować? Na swoim sekretnym blogu bohaterka Tego grubego odnotowuje:

Poznanie pani M. [nauczycielki - przyp. W. K.] było dla mnie prawdziwym przełomem, ponieważ była jedyną osobą, która otwarcie nazywała przykre rzeczy po imieniu, bez zbędnych eufemizmów. Już pierwszego dnia obejrzała mnie od stóp do głów i śmiało popatrzyła mi w oczy (bez ukradkowego zerkania, którego nienawidzę!). I powiedziała:

- Ej, nie jest z tobą tak źle, połamańcu... jaki zgrabny wózek! Już ze mną jest gorzej, bo chociaż mam sprawne nogi, mówią, że poruszam się jak niedźwiedź20

Podobną chęć nazywania rzeczy po imieniu i podobne zniecierpliwienie rzucanymi ukradkiem spojrzeniami, pełnymi współczucia lub źle ukrywanej żądzy sensacji, przejawiają także pozostałe dwie bohaterki przywołanych tu powieści. Jak wskazują wymienione autorki, zarówno postawa wrogości, jak i litości wobec Innego-niepełnosprawnego stygmatyzuje; Ciwoniuk, Landau i Nowak poprzez swoje opowieści pośrednio postulują przyjęcie takiej perspektywy, jaką Joanna Głodkowska określa - w odniesieniu do idei tzw. normalizacji - jako próbę „wspólnego doznawania świata”21:

Ponawiane odczytywanie normalizacji pozwala również dzisiaj widzieć ten proces jako żywy nurt, w którego centrum znajduje się osoba z niepełnosprawnością i jej życie. Daje także możliwość rozpoznawania i rozpatrywania różnych problemów i dylematów dotyczących m.in. różnicowania i unifikacji w określaniu norm, definiowania normalności i przyjmowania standardów funkcjonowania człowieka, czy też ujmowania normalizacji bez upiększeń jako instrumentu władzy i narzędzia przemocy symbolicznej [...]. Mimo różnic w interpretacji i niejednoznacznych ujęć, dominuje rozpatrywanie normalizacji w kategoriach dążenia do wspólnego doznawania świata przez sprawnych i niepełnosprawnych oraz wspólnego ich bytowania. Wspólnotowe podejście niesie ze sobą nie zawsze łatwe w realizacji wymagania. Jednym z nich jest konieczność większej otwartości sprawnego społeczeństwa na zrozumienie i przyjęcie Innego ${ }^{22}$.

W istocie, wszystkie trzy autorki snują opowieść o zderzeniu społecznych norm z tym, co od tych norm odbiega, „normalności” z innością, o reakcjach reprezentantów sprawnego społeczeństwa na niepełnosprawność. Ukazują też, w takim właśnie kontekście, autorefleksję Innego. Landau, poza zobrazowaniem zmagań swojej bohaterki z nową dla niej rzeczywistością, autorefleksji tej nadaje, w następującym fragmencie, także wymiar dydaktyczny:

19 Zob. E. Nowak, Dane wrażliwe, Warszawa 2011.

20 B. Ciwoniuk, Ten gruby, s. 82.

21 J. Głodkowska, Być podmiotem i stawać się autorem swojego życia - paradygmat wsparcia w przygotowaniu osób z niepełnosprawnościa do budowania własnej tożsamości i wzbogacania dobrostanu, „Człowiek Niepełnosprawność - Społeczeństwo" 2014, nr 4, s. 29.

22 Ibidem, s. 29. 
Wpadło mi do głowy, że może Renia nie chce się pokazywać z kimś, kto siedzi na wózku. Wstydzi się. To obrzydliwe, ale ja ją nawet rozumiem. Nie mogę zapomnieć, jak kiedyś nie chciałam się bawić w przedszkolu z jednym chłopczykiem, który nie miał ucha. Pies mu je odgryzł. Wydawało mi się to paskudne, a to ja sama byłam paskudna ${ }^{23}$.

Ciwoniuk z kolei konfrontuje załamaną przykuciem do wózka bohaterkę z bohaterem cierpiącym z powodu znacznej, widocznej i uciążliwej otyłości, będącej częstym powodem drwin ze strony rówieśników. Tytuł powieści: Ten gruby nawiązuje wyraźnie do pozycji z polskiego kanonu literatury młodzieżowej, czyli do Tego obcego Ireny Jurgielewiczowej $(1961)^{24}$; zarówno niesprawność fizyczna, jak i „niestandardowy” wygląd wykluczają bohaterów z grona „swoich”. Jednocześnie, poznając się wzajemnie i nawiązując między sobą głębszą relację, oboje zyskują inną perspektywę autorefleksji, a więc oglądu i oceny własnej odmienności.

\section{Inny-niepełnosprawny: odmienność intelektualna}

Codzienne próby zmierzenia się z trudną rzeczywistością stają się również udziałem osób niepełnosprawnych umysłowo i ich rodzin. Wspomniana już Wyspa mojej siostry Katarzyny Ryrych jest opowieścią o dziewczynie z zespołem Downa, prowadzoną z perspektywy jej młodszej siostry. Mimo swojego upośledzenia Pippi przez lata dba o małą Marysię i daje jej poczucie bezpieczeństwa, zastępując matkę; gotuje, uczy, jak zapinać guziki, jest wspaniałą towarzyszką dziecięcych zabaw. Jednakże gdy Marysia dorasta, role sióstr zaczynają się odwracać. Nie jest to łatwy proces; relacje między postrzegającą świat we właściwy tylko sobie sposób Pippi a jej rodziną są coraz bardziej skomplikowane, choć zawsze pełne miłości i akceptacji. „Kiedy myślę o tym, jak żyje Pippi - tłumaczy bohaterka-narratorka - przychodzi mi na myśl ocean. [... ] Na powierzchni tego życia Pippi jest dorosłą kobietą, która raz w miesiącu kupuje sobie w sklepie kolorowe paczuszki, a w głębi jest małą dziewczynką, taką samą jak ja”2s. O ile jednak Marysia oswajała się z odmiennością swojej siostry od urodzenia i dlatego w pełni tę odmienność akceptuje, o tyle osoby z zewnątrz nie wiedzą często, jak reagować - ich postawa wobec niepełnosprawnej dziewczyny czasami wyraża strach i niechęć, czasami drwinę, a czasami zwykłe ludzkie zaciekawienie „dziwnością” napotkanej osoby. Podobne ujęcie tematu przedstawia Beata Wróblewska w Jabłku Apolejki í, opowieści o autystycznym chłopcu i jego rodzinie. Tytuł książki nawiązuje do baśni o królewnie Apolejce i osiołku. Baśniowy osiołek po zjedzeniu zaczarowanego jabłka zmienia się w królewicza, jednak ponieważ jabłko było nadgryzione, na ludzkim ciele pozostaje ośla głowa;

23 I. Landau, op. cit., s. 51.

24 Uzasadnionym skojarzeniem byłaby tu także powieść pt. Gruby Andrzeja Minkowskiego (1966), której bohaterem jest otyły chłopiec borykający się, jako „odmieniec”, z problemem trudnych relacji ze szkolnymi rówieśnikami.

25 K. Ryrych, op. cit., s. 17.

26 Zob. B. Wróblewska, Jabłko Apolejki, Warszawa 2007. 
cierpiący na autyzm Jasiek, kochany przez swoją rodzinę tak jak królewicz-osiołek przez Apolejkę, nigdy nie stanie się takim człowiekiem jak jego bliscy, pozostanie „zaklęty” już na zawsze. Część osób spoza jego rodziny zaakceptuje jego odmienność, dla części pozostanie odmieńcem wzbudzającym niepokój, zdziwienie lub rozbawienie.

Obie autorki prowadzą narrację swoich opowieści w taki sposób, by czytelnik czuł się traktowany po partnersku: nie formulują pouczeń ex cathedra, nie przemawiają do niego z pozycji mentorskiej, nie starają się go ukarać za ewentualną nieumiejętność porozumienia z Innym - zostawiają miejsce na czytelniczą refleksję, co najwyżej konstatując, jak to czyni na przykład Wróblewska ustami swojego bohatera, że „ludzie zawsze odrzucają tych, którzy od nich się różnią. A zawsze są tacy, którzy różnią się wyglądem, religią, zachowaniem, sposobem życia ... Taka jest ludzka natura"27. Formułując taką konstatację na temat naturalnego mechanizmu działania ludzkiej psychiki, autorka potwierdza niejako rozpoznania o charakterze naukowym:

Postrzeganiu grona osób jako jednej grupy, pewnej całości, która odróżnia się od innych, sprzyja kategoryzacja społeczna (Wojciszke, 2011, s. 487; Tajfel, 1981). Jej istotą jest proces inkluzji, czyli włączania do pewnej kategorii osób spełniających te same kryteria, i jednoczesny proces ekskluzji, polegający na wyłączaniu z owej kategorii tych osób, które nie spełniają kryteriów przynależności do niej. Rozpoznawanie podobieństw i różnic pomiędzy osobami i grupowanie ich w oddzielne kategorie jest korzystne z psychologicznego punktu widzenia sprawności poznania i działania. Kategoryzacja społeczna odpowiedzialna jest za zjawisko faworyzowania „swoich” i dyskryminowania „innych”, „obcych” (Miluska, 2008, s. 13). Zjawisko to, z jednej strony, zwiększa spójność grupy, poczucie wartości osobistej i wyraża się w nawiązywaniu częstych i bliskich kontaktów z członkami własnej grupy, z drugiej zaś - członkowie grupy obcej traktowani są niechętnie, podejrzliwie, są gorzej oceniani, pomijani czy wręcz izolowani ${ }^{28}$.

Tak Ryrych, jak Wróblewska przeprowadzają również demitologizację inności. Nie jest prawdą, dowodzi ta pierwsza, że osoba z zespołem Downa nie potrafi być wsparciem dla swoich bliskich. Nie jest też prawdą, jak pokazuje druga z powieściopisarek, że z cierpiącym na autyzm nie da się porozumieć, a jego bliscy skazani są na wieczną udrękę.

Przykładem demitologizacji dysfunkcji intelektualnej, jaką stanowi dysleksja, jest powieść Igor ${ }^{29}$ Barbary Ciwoniuk. Autorka przedstawia perypetie tytułowego bohatera, który ma ogromne problemy z czytaniem, pisaniem i koncentracją uwagi. Do ostatecznego zburzenia stereotypu dyslektyka jako osoby mającej złe wyniki w nauce, niezdolnej i „gorszej” pod względem intelektualnym, posłużyła opinia pedagogiczna, jaką Igor otrzymuje ze specjalistycznej poradni, po przejściu odpowiednich badań i testów:

Stwierdza się inteligencję bardzo wysoką badanego ucznia. Istotne funkcje intelektu: myślenie, zdolność planowania, zasób słownictwa, inteligencja niewerbalna i wyobraźnia przestrzenna, a także zdolność uczenia się specyficznych typów nowych zadań są bardzo dobrze rozwinięte. [...] W sytuacji stresu obniżona jest samokontrola (chaos myślowy w momencie kulminacji emocji) zwiększając częstotliwość występowania błędów. Uczeń jest ambitny, ale ze względu na

\footnotetext{
27 Ibidem, s. 99.

28 A. Tłuściak-Deliowska, Dystans społeczny wobec innych: analiza postaw młodzieży wobec wybranych grup narodowo-etnicznych, „'Człowiek - Niepełnosprawność - Społeczeństwo” 2014, nr 4, s. 85-86.

29 Zob. B. Ciwoniuk, Igor, Warszawa 2005.
} 
popełniane błędy brak jest jego wiary we własne możliwości - bywa niepewny. Pracuje szybko i chętnie, dobrze współpracuje ${ }^{30}$.

Inność, zwłaszcza ta, która wiąże się z cierpieniem, nie pozostaje bez wpływu - jak to zostało już powiedziane - na najbliższe otoczenie naznaczonej ową odmiennością osoby. Bliscy Innego sami stają się inni, inność zaś bywa powodem osamotnienia (czasem - samotności z wyboru), odrzucenia czy poczucia wstydu. „[... ] nagle dotarło do mnie - zauważa bohaterka powieści Ryrych - że Tata, podobnie jak ja, nie ma wstępu do reszty świata. I tak jak ja jest sam, ale to nie jest wina Pippi ani moja, ani niczyja. Po prostu inni boją się jego wyspy, na której nie ma przecież potworów ani ludożerców, tylko Tata, Pippi, ja i nasz gruby pies"31. Wróblewska opowiada o rozterce kilkuletniej Oli, która wstydzi się zaprosić do domu inne dzieci w obawie, że znajomi wyśmieją ją po tym, jak zobaczą dziwne zachowanie jej autystycznego brata. I choć dziewczynka pokonuje w końcu strach przed odrzuceniem i opowiada o chorobie Jaśka przy całej klasie, czytelnik jest w pełni świadomy, że jej obawy nie były bezpodstawne. Inność bywa powodem drwin, bywa także powodem litości lub podziwu; odczucia te, choć pozornie pozytywne, zamykają jednak Innego w ciasnych ramach stereotypu i sprowadzają jego człowieczeństwo do tej jedynej cechy; takie zjawisko opisuje Ciwoniuk poprzez wypowiedź matki niepełnosprawnej bohaterki:

- Myślą, że nasze życie jest wyłącznie smutne i czarno-białe... że inne być nie może!... więc albo litują się nad nami, albo nas podziwiają! Mam każdemu thumaczyć, jak jest naprawdę? Że dziecko na wózku daje mi ogromne szczęście? Że to nie są wyłącznie zmartwienia i kłopoty? ... że jak inni miewamy chwile radości i smutków, wygłupiamy się, pieczemy sobie pyszności, czytamy książki i oglądamy filmy, układamy puzzle, żartujemy, po prostu ... żyjemy normalnie?! Niech sobie patrzą na nas tylko przez pryzmat wózka... Może dzięki temu czują się od nas lepsi? Ale nie życzę sobie, żeby ktoś się nad nami z tego powodu litował lub nas podziwiał! ${ }^{32}$

Frapujące „studium inności” stanowi Oro ${ }^{33}$ Olgi Sawickiej i Dany Łukasińskiej. Z odmiennością postrzeganą przez społeczeństwo jako problem zmaga się każdy członek sportretowanej przez autorki rodziny zastępczej. „Odmieńcem” jest Lena - główna bohaterka: introwertyczka, zagubiona w gąszczu bardzo trudnych, raniących emocji. Poza społeczną „normą” bytuje jej adopcyjne rodzeństwo, naznaczone różnego rodzaju dysfunkcjami fizycznymi i psychicznymi. Wreszcie, z innością mierzą się nieustannie adopcyjni rodzice szukający odpowiednich dróg komunikacji ze swoimi podopiecznymi, ale i sami będący Innymi, bo wychowującymi nie-normalne dzieci.

\footnotetext{
30 Ibidem, s. 36.

31 K. Ryrych, op. cit., s. 73.

32 B. Ciwoniuk, Ten gruby, s. 63.

33 Zob. O. Sawicka, D. Łukasińska, Oro, Warszawa 2012.
} 


\section{Inny-niepolski}

„[... ] trzy możliwości - pisze Kapuściński - stały zawsze przed człowiekiem, ilekroć spotkał się z Innym: mógł wybrać wojnę, mógł odgrodzić się murem, mógł nawiązać dialog”34. Osoba odmiennej narodowości jest nie tylko inna - jest także obca. Przybywa z zewnątrz, zdradza swoją obcość nieznajomością języka, innym kolorem skóry, odmiennymi rytuałami, różniącą się od dominującej hierarchią wartości. Jak wskazują współcześni badacze literatury dziecięcej i młodzieżowej, twórczość ta niejednokrotnie odgrywa niebagatelną rolę w tworzeniu nie tylko poczucia tożsamości narodowej hipotetycznego czytelnika, lecz także pozytywnych relacji między odmiennymi grupami etnicznymi ${ }^{35}$. W odniesieniu do polskiej literatury dla niedorosłego czytelnika jest to tym bardziej istotne, że, jak podaje Aleksandra Tłuściak-Deliowska, stosunek najmłodszych Polaków do mniejszości narodowych okazuje się problematyczny:

Pierwsze analizy postaw dzieci i młodzieży wobec różnych narodów pojawiły się w Polsce w latach 60. XX w. (Kłoskowska, 1961, 1962) i od tamtego czasu, w związku z coraz większym zróżnicowaniem narodowym i kulturowym, prowadzone są częściej. Generalnie badania te pokazują, że stosunek do „obcych”, „innych”, „odmiennych” zostaje ukształtowany relatywnie wcześnie. Szczególnie negatywne sądy formułowane są przez dzieci, jak i młodzież w odniesieniu do Romów, Żydów, Rosjan i Ukraińców. Wiele wyników badań wykazuje duże podobieństwo w zakresie tych uprzedzeń (por. Weigl, 2008, 1999; Karolczak-Biernacka, 1995; Weigl, Łukaszewski, 1992; Misiejuk, 1995; Czykwin, 1995; Wilska-Duszyńska, 1993; Stachyra, 1992). Szczególnie dwie grupy mniejszościowe, tj. Cyganie i Żydzi, są obiektem wyraźnej dyskryminacjii ${ }^{36}$.

Badania przeprowadzone przez wspomnianą autorkę potwierdzają wcześniejszą diagnozę: „największy dystans społeczny, a zatem największe uprzedzenie badana młodzież wyraża w stosunku do Żydów, Romów i Arabów" ${ }^{37}$. Nawet jeśli w istocie różnice między „swoim” a „obcym” nie istnieją lub też nie są w żaden sposób znaczące, samo podejrzenie obcości wystarczy, by implikowała ona postawę wrogości. Taki przypadek przedstawia Grzegorz Gortat w powieści Szczury i wilki ${ }^{38}$, ukazując losy Henryka, współczesnego nastolatka zaangażowanego w walkę o „czystość” polskiej krwi u boku kolegów z neofaszystowskiej bojówki. Uwielbiany przez niego lider grupy, kryjący się za pseudonimem A. H. w oczywisty sposób nawiązującym do imienia i nazwiska przywódcy nazistowskiej III Rzeszy - wpaja swoim podopiecznym (a czyni to skutecznie) wizję osaczania „prawdziwych Polaków” przez podstępnych „obcych”, przede wszystkim Żydów.

- Uwierz mi, Heinrich - tłumaczy A.H. - choćbyś ukończył to swoje liceum z wyróżnieniem, takich jak ty uniwersytet wykopie już po pierwszym semestrze. Bo upominamy się o prawdę. O miejsce dla siebie w kraju, który już tylko z nazwy jest Polską. Dziewięćdziesiąt procent ty-

34 R. Kapuściński, Spotkanie z Innym jako wyzwanie XXI wieku, [w:] idem, Ten Inny, s. 67.

35 Zob. C. Bradford, Race, Ethnicity, and Colonialism, [w:] The Routledge Companion to Children's Literature, ed. D. Rudd, New York 2010, s. 47 i nast.

36 A. Tłuściak-Deliowska, op. cit., s. 88-89.

37 Ibidem, s. 100.

38 Zob. G. Gortat, Szczury i wilki, Warszawa 2009. 
tułów na półkach tej biblioteki to trucizna, która zatruwa naszą gospodarkę, historię i literaturę. Ich autorzy to bękarty chowające się za dobrymi, polskimi nazwiskami. Trzęsą giełdą, dyktują ceny i na pniu wykupują apartamentowce takie jak te. Rozkradają Polskę kawałek po kawałku. Dom po domu, ulica po ulicy. Aż zamkną nas w getcie ${ }^{39}$.

Gortat ukazuje skrajny - choć nieodosobniony - przykład lęku przed Innym, lęku przeradzającego się w bezpodstawną i bezsensowną nienawiść. $Z$ kolei na problem pozornie niewinnych żartów z odmienności narodowej zwraca uwagę Ewa Grętkiewicz w powieści Szczekająca szczęka Saszy ${ }^{40}$. Mieszkający na co dzień na Białorusi kuzyn głównej bohaterki (i zarazem narratorki) przyjeżdża do Polski, by przez rok uczyć się w tutejszej szkole. Ojczyzna jego dziadków, której był ciekawy dzięki rodzinnym opowieściom i wspomnieniom, nie okazuje się jednak tak gościnna, jak sobie wymarzył. Pozwalając czytelnikom spojrzeć na rzeczywistość z perspektywy tego bohatera ${ }^{41}$, autorka stwarza im szansę na to, co Shaobo Xie określa jako „zredefiniowanie i zrenarratywizowanie świata”42. Niewątpliwie taka zmiana w postrzeganiu i wyjaśnianiu sobie rzeczywistości, bezrefleksyjnie opisywanej w kategoriach swojskości i obcości, jest potrzebna, ponieważ krzywdzące stereotypy funkcjonują już w myśleniu najmłodszych uczniów szkoły podstawowej: koledzy drwią ze specyficznej - w ich odczuciu dziwnej, gorszej i żenującej - polszczyzny Saszy i zadają mu złośliwe pytania o to, czy na Białorusi ludzie posługują się telefonami komórkowymi, czy są tam wieżowce i supermarkety. Gdy otrzymują odpowiedzi twierdzące, zadają jeszcze jedno pytanie, nie zdając sobie sprawy z jego kompromitującego charakteru: „To po co tu przyjechałeś?" ${ }^{43}$. Wbrew pozorom od takiego podejścia niebezpiecznie blisko jest do tego opisanego przez Gortata. Ogniwem pośrednim okazuje się narastająca wrogość wynikająca z niezrozumienia motywacji Innego i jego obecności w nie-swoim miejscu, podsycana myślowymi stereotypami, bez jakiejkolwiek próby ich weryfikacji:

- Mówiłeś, że u was na Białorusi wszystko jest, Szczekająca Szczęko! A tu proszę, do Polski się żebrać przyjechało!

- Na co zbieramy? Na bilecik w rodzinne strony? ${ }^{44}$

Tego typu dyskurs, przejawiający się w nieprzyjaznym odnoszeniu się do Innego, ujawnia utożsamianie „dziwności”, „obcości” z „gorszością”. Między światem znanym i „swoim” a dziwnym i „nie-swoim” przebiega linia graniczna oddzielająca to, co wartościowe (i dlatego wymagające obrony), od tego, co gorsze, „niepełnowartościowe” i zatruwające „swojość", a więc stanowiące zagrożenie wymagające odseparowania. Jak wskazuje Mieczysław Dąbrowski:

39 Ibidem, s. 16.

40 E. Grętkiewicz, Szczekająca szczęka Saszy, Warszawa 2005.

41 Narracja prowadzona jest z perspektywy kuzynki Saszy - Polki, jednakże autorka wyraźnie dąży do umożliwienia czytelnikowi identyfikacji z białoruskim chłopcem (jako Innym) czy choćby podjęcia próby zrozumienia odczuć tego bohatera.

42 S. Xie, Rethinking the Identity of Cultural Otherness: The Discourse of Difference as an Unfinished Project, [w:] Voices of the Other: Children's Literature and the Postcolonial Context, ed. R. McGillis, New York 1999 , s. 1.

43 E. Grętkiewicz, op. cit., s. 44.

44 Ibidem, s. 93. 
Opozycja swoje/obce w tle sugeruje obecność granicy, jakiegoś przejścia między jednym a drugim polem; linii, słowa, obyczaju, które tyleż łączą, co dzielą. Antropologiczna analiza tego pojęcia pozwala dostrzec wiele znaczeń; to coś, co odgranicza „nasze” od „obcego” (nie „naszego"), z jednej strony jest zabezpieczeniem, z drugiej otwarciem się na chaos tego, co na zewnątrz, co jest obce, groźne bądź czego nie znamy. Jest przejściem od sacrum do profanum, gdyż w obrębie „naszego” świata wytwarzamy zawsze pewien rodzaj centrum, jakieś sacrum właśnie, podczas gdy wszystko to, co znajduje się na zewnątrz, czego nie znamy, co zagraża, rozumiane bywa jako świat brudny, obcy i przeklęty ${ }^{45}$.

Stosując odmienne typy narracji, kształtując opowieść dla czytelników z różnych grup wiekowych, przedstawiając problem z odmiennych perspektyw - autorzy wspomnianych dwóch powieści mówią jednak o tym samym zjawisku: irracjonalny lęk przed innością i bezrefleksyjne postrzeganie świata za pomocą krzywdzących stereotypów prowadzą do agresji wobec wszystkich, którzy nie są jednoznacznie „swoi”. To głos istotny tym bardziej, że ukazujący działania opresyjne wobec Innego prowadzone przez dzieci (Grętkiewicz) i nastolatków czy wręcz „młodych dorosłych” (Gortat). W rozważaniach nad kategorią inności w utworach adresowanych do dzieci i młodzieży to zagadnienie - problem uwypuklania cudzej „obcości”, piętnowania jej i stygmatyzowania „Obcego” - jest nie mniej ważne niż rozpatrywanie samej figury Innego ucieleśnionej w postaci dziecka.

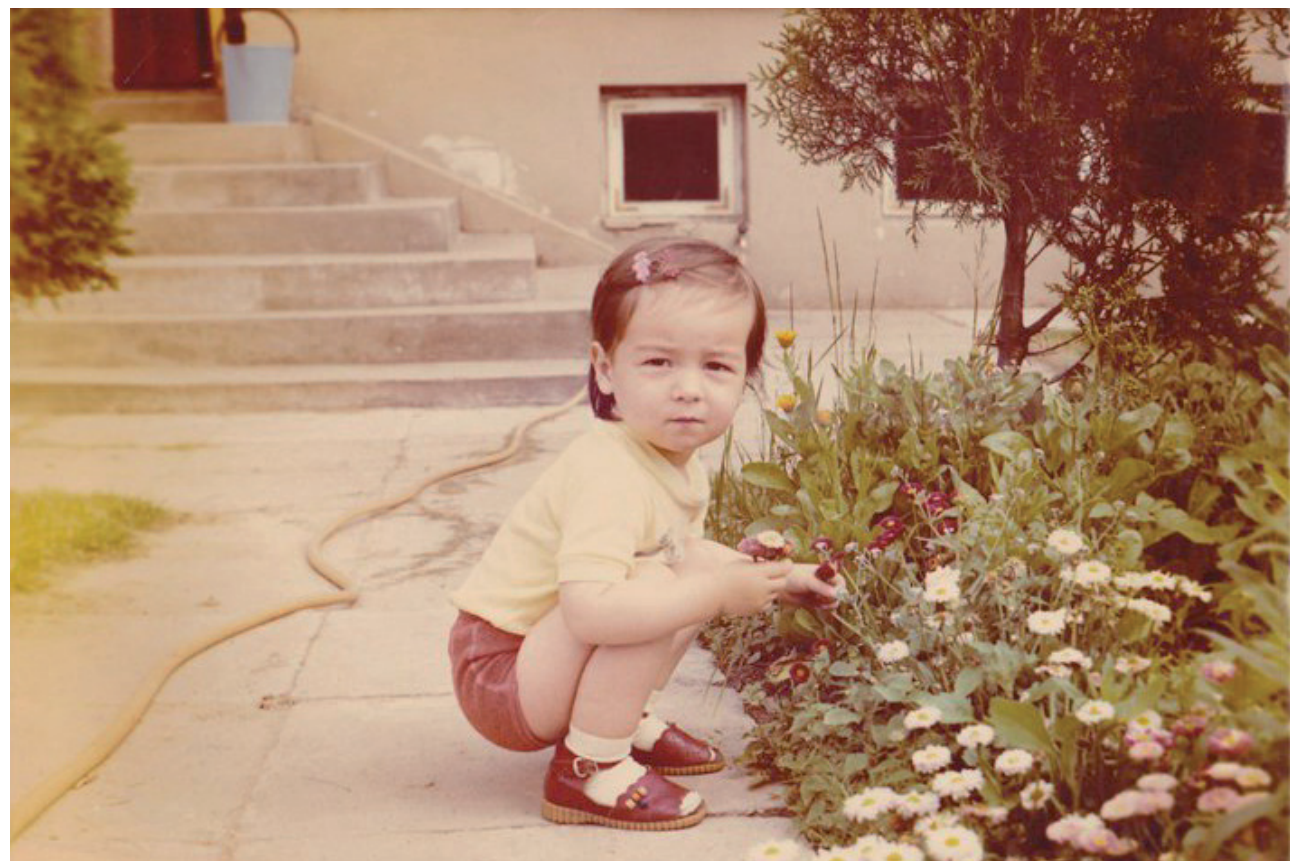

Dziewczynka zrywająca kwiaty, lata 80 . XX wieku.

$\mathrm{Z}$ archiwum redaktorów naukowych tomu.

${ }^{45}$ M. Dąbrowski, op. cit. 


\section{Ja jako Inny}

Inność i obcość ukazywana jest w polskiej literaturze dla młodego czytelnika z wielu różnych perspektyw; to nie tylko spotkanie z Innym, zetknięcie się z jego odmiennością, lecz także sytuacja, w której to j a staję się Innym. O powieści Ireny Landau Uszy do góry!, przedstawiającej losy dziewczyny, która po utracie władzy w nogach uczy się żyć na nowo, była już mowa. W kontekście wcześniejszych rozważań o inności narodowej ciekawym casusem okazuje się powieść Barbary Gawryluk pt. Moje Bullerbyn ${ }^{46}$ : główna bohaterka, nastoletnia Natalia, emigruje wraz z rodzicami do Szwecji i zmaga się z problemami, jakimi są dla niej początkowo nowa kultura, niedostateczna znajomość języka angielskiego i zupełna nieznajomość szwedzkiego, nowe środowisko rówieśnicze itd. Co więcej, dotychczasowa „swojskość”, w nowych realiach przekształcająca się w „obcość”, staje się powodem do żartów - opozycja prezentowana przez Ewę Grętkiewicz zmienia tutaj kierunek oddziaływania: „polskość” staje się powodem problemów, a nie fundamentem kultury dominującej.

Nie znoszę Matsa [kolegi ze szkoły w Szwecji - przyp. W. K.]! Jest okropny! Od początku mi dokuczał, a teraz jest tylko gorzej. Dzisiaj znowu od rana chodził za mną i za Mają i przedrzeźniał nas. „Szczszcz, szczszcz!” - udawał, że coś do nas mówi. Potem wybuchał śmiechem. A najgorsze jest to, że Mats nie jest sam. Chodzi za nim zawsze trzech albo czterech chłopaków z naszej klasy. Zakradają się za naszą ulubioną ławkę pod jabłonią. „Szczszcz, szczszcz!” - wygłupiają się ${ }^{47}$.

Z kolei Katarzyna Pranić w powieści Ela-Sanela ${ }^{48}$ opisuje doświadczenia Saneli Hasani, dziewczynki pochodzącej z Sarajewa, w wyniku wojennych wydarzeń z 1993 r. adoptowanej i wychowywanej przez Polkę. Sanela powoli poznaje historię swojej rodziny, dowiaduje się coraz więcej o swoich korzeniach, swoim kraju i rodzinnym mieście, analizuje różnice między polską kulturą, a więc tą, w której została wychowana, a kulturą regionu, w którym się urodziła. Zaczyna akceptować siebie jako „dziewczynkę trochę stąd, a trochę z innego świata, którego sama jeszcze nie znała, chociaż ten nieznany świat dopominał się, żeby zaczęła go odkrywać. I Ela była na to gotowa, bo wiedziała, że czekają tam na nią ludzie, którzy ją kochają i za nią tęsknią. Nieważne, jakiego są pochodzenia i wyznania" ${ }^{49}$.

Jednocześnie autorka wskazuje na mechanizm zyskiwania przez pojęcie obcości nacechowania pejoratywnego, które jest temu pojęciu nadawane przez „swoich” użytkowników języka:

Ela, idąc za Martą przez półmroczny korytarzyk, postanowiła zignorować tę sytuację [nazwania jej przez szkolnego kolegę „alienem” - przyp. W. K.], ale było jej przykro. Alien - obca. Bo co? Bo nie ma w klasie swojej paczki? A może dlatego, że jej imię i nazwisko brzmi inaczej? Ci, którzy słyszeli je pierwszy raz, zawsze byli nieco zdziwieni, ale Ela czuła, że Michał powiedział

\footnotetext{
46 Zob. B. Gawryluk, Moje Bullerbyn, Łódź 2010.

47 Ibidem, s. 45.

48 Zob. K. Pranić, Ela-Sanela, Warszawa 2011.

49 Ibidem, s. 231. Według Małgorzaty Chrobak "główny element konstrukcji bohaterki powieści Ela-Sanela należałoby raczej wyrazić słowem osobność"; M. Chrobak, Uczq̨c się od Jurgielewiczowej, s. 86.
} 
to specjalnie, żeby zrobić jej przykrość. Ela-Sanela. Właśnie że tak! Sanela Hasani! Czuła, jak palą ją policzki ${ }^{50}$.

W scenie, w której Ela-Sanela dowiaduje się, że jej rodzina prawdopodobnie kultywuje odmienne, nieznane dziewczynie rytuały religijne, Pranić ukazuje wątpliwości i rozterki tożsamościowe swojej bohaterki:

- Jak to? Nie obchodzą świąt [krewni Eli - przyp. W. K.]?

- Bożego Narodzenia - nie. W islamie obchodzi się inne święta.

- Islam? - Ela była kompletnie zaskoczona. - Chcesz powiedzieć, że wierzą w Allaha i chodzą do meczetu?

- Nie wiem. Może? W każdym razie jest mało prawdopodobne, żeby obchodzili nasze Boże Narodzenie. Ich tradycja jest inna niż nasza. [... ]

- Gdybym nazywała się Sanela Nowak, to miałabym tylko oryginalne imię. Ale ja też jestem Hasani. Tak jak oni. Muszę cię w takim razie zapytać: czy ja powinnam być muzułmanką?

Babcia, zaskoczona, zatrzymała się z ciężkim żyrandolem w progu.

- Elu, wyznania się nie dziedziczy jak kolor oczu. Gdybyś była tam, z nimi, a nie tu, ze mną, to zapewne nie byłabyś też taką samą Sanelą jak w tej chwili. Wychowano by cię inaczej. Miałabyś inne przyzwyczajenia, co innego byś lubiła. Ale nie ma żadnej pewności, że byłabyś muzułmanką. A może twój dziadek jest ateistą ? $^{51}$

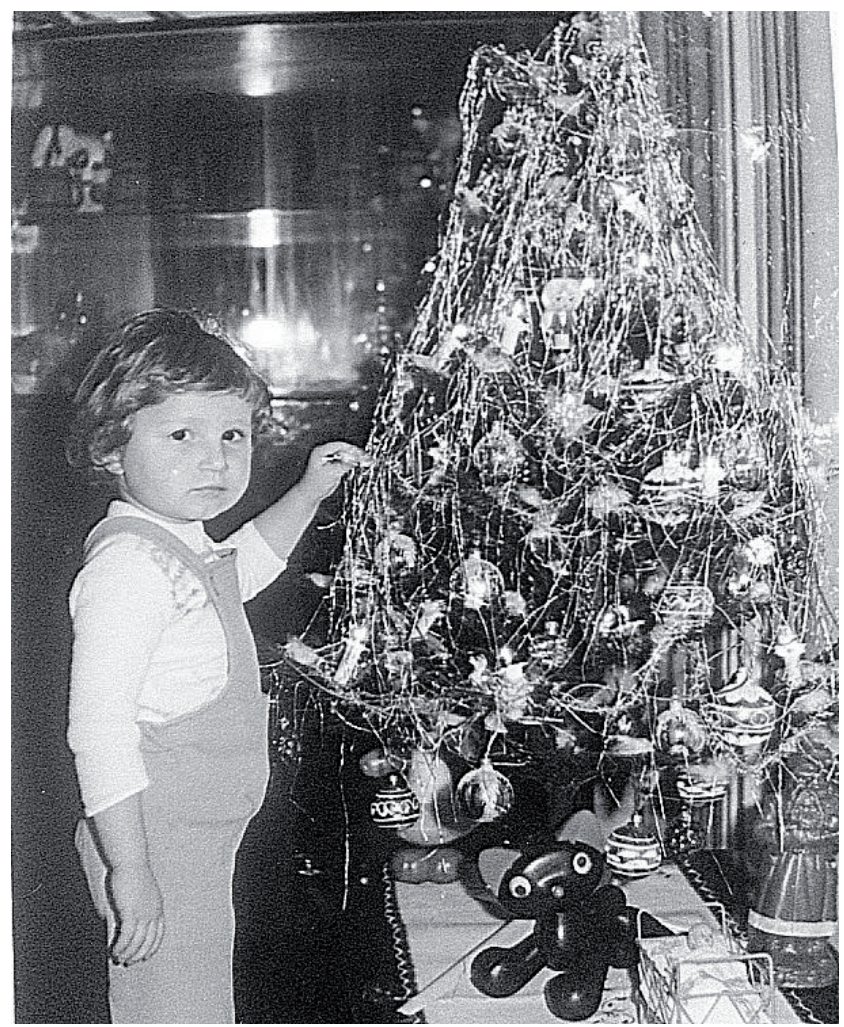

Dziewczynka przy choince, lata $80 . \mathrm{XX}$ wieku. Z archiwum redaktorów naukowych tomu.

\footnotetext{
50 E. Pranić, op. cit., s. 177.

51 Ibidem, s. 229-230.
} 
Odkrywając powoli nieznaną jej dotąd część swojej tożsamości, będąc osobą związaną z dwoma odrębnymi kulturowo regionami świata, bohaterka staje przed koniecznością refleksji nad takimi zagadnieniami, jak związek między przynależnością etniczną a kultywowanymi rytuałami (w tym wypadku związanymi z religią).

\section{Zakończenie}

Stosując różne strategie narracyjne i wykorzystując rozmaite pomysły fabularne, twórcy polskiej literatury dziecięcej i młodzieżowej mówią o tym samym: inność nie jest problemem - problemem jest brak akceptacji faktu istnienia inności, brak chęci podjęcia wysiłku, by ją zrozumieć, brak uznania różnorodności za wartość. Receptą wydaje się wzbudzenie ciekawości w stosunku do tego, co jeszcze niepoznane, zafascynowanie różnorodnością i „dziwnością”, dekonstruowanie stereotypów, pokazywanie inności jako frapującego wyzwania dla czytelnika. „Świadomość tego, że rozmawiając z Innym, obcuję z kimś, kto w tym samym momencie widzi świat odmiennie niż ja i inaczej go rozumie, jest ważna w tworzeniu atmosfery pozytywnego dialogu”22, pisze Kapuściński. Wyrazem takiej świadomości jest np. zbiór Dziesięć stron świata ${ }^{53}$ Anny Onichimowskiej, w którym autorka opisuje doświadczenia nastolatków mieszkających w różnych miejscach globu, przyglądając się rzeczywistości z perspektywy swoich bohaterów. Przedstawia m.in. losy Kolumbijki, która zarabia na życie własnym ciałem, aż w końcu udaje jej się spełnić marzenia i zostaje królową samby, Dunki, zmagającej się z zainteresowaniem mediów w związku ze ślubem jej matki z wieloletnią przyjaciółką, czy mieszkającego w USA Pakistańczyka, który zmuszany jest do udziału w przygotowaniach do zamachu terrorystycznego. Do wzajemnego szacunku, niedawania wiary stereotypom, chęci poznawania tego, co inne, i czerpania radości z różnorodności świata nawołuje młodszych czytelników Magdalena Środa w pierwszej polskiej książce z wydawanej przez oficynę Czarna Owca serii „Bez Tabu”; Mała książka o tolerancji $^{54}$ łączy formę opowiadania, leksykonu (zawiera objaśnienie kluczowych pojęć) i podręcznika (prezentuje m.in. historię pojęcia tolerancji).

Zarówno spotkanie z Innym, jak i zmierzenie się z własną innością czy też bycie innym z własnego wyboru wymaga odwagi, wewnętrznej dojrzałości, otwarcia się na to, co nowe. Polska literatura dla dzieci i młodzieży bez wątpienia podejmuje wyzwanie, jakim jest zwrócenie uwagi niedorosłego odbiorcy na tego rodzaju zagadnienia i oswojenie go z nimi. Poprzez stwarzanie szansy na identyfikację z bohaterem-rówieśnikiem hipotetycznego dziecięcego czy też nastoletniego czytelnika - bohaterem jawiącym się jako Inny bądź też bohaterem poznającym Innego - czytelnik ów jest więc zachęcany do refleksji nad pojęciem inności oraz etykietującą dychotomią: „swojskość” versus „obcość”. Zyskuje możliwość namysłu nad kształtowaniem się tożsamości w sensie socjologicznym, kulturoznawczym i psychologicznym, w opozycji do rozmaicie pojmowanej inności i obcości (cudzej lub własnej). Nie są to zazwyczaj książki z list bestsellerów, raczej nie mieszczą się w ramach

52 R. Kapuściński, Wykłady wiedeńskie III, [w:] idem, Ten Inny, s. 35.

53 Zob. A. Onichimowska, Dziesięć stron świata, Kraków 2007.

54 Zob. M. Środa, Mała książka o tolerancji, Warszawa 2010. 
najpopularniejszych czytelniczych trendów, są - paradoksalnie - w jakimś sensie inne; i to także stanowi wyzwanie dla czytelnika.

\section{Bibliografia}

Bauman Zygmunt, Płynna nowoczesność, przeł. Tomasz Kunz, Kraków: Wydawnictwo Literackie, 2006.

Bradford Clare, Race, ethnicity, and colonialism, [w: The Routledge Companion to Children's Literature, ed. David Rudd, New York: Routledge, 2010.

Budyta-Budzyńska Małgorzata, Socjologia narodu i konfliktów etnicznych, Warszawa: PWN, 2010.

Chrobak Małgorzata, Obcość jako kategoria interpretacyjna w badaniach nad dzieciństwem i literatura dla dzieci, [w:] Children studies jako perspektywa interpretacyjna. Studia i szkice, red. Jolanta Sztachelska, Karolina Szymborska, Białystok: Wydawnictwo Uniwersytetu w Białymstoku, 2014.

—, Uczac się od Jurgielewiczowej. Inna w powieści Katarzyny Pranič „Ela-Sanela”, [w:] Wyczytać świat - międzykulturowość w literaturze dla dzieci i młodzieży, red. Bernadeta Niesporek-Szamburska, Małgorzata Wójcik-Dudek, Aleksandra Zok-Smoła, Katowice: Wydawnictwo Uniwersytetu Śląskiego, 2014.

Ciwoniuk Barbara, Igor, Warszawa: Telbit, 2005.

—, Ten gruby, Kraków: Znak, 2011.

Dąbrowski Mieczysław, Swój / obcy / inny. Kontynuacja, „Anthropos?” 2009, nr 12/13, http://www. anthropos.us.edu.pl/anthropos7/texty/dabrowski.htm (dostęp: 22.10.2015).

Gawryluk Barbara, Moje Bullerbyn, Łódź: Akapit Press, 2010.

Giddens Anthony, Socjologia, przeł. Alina Szulżycka, Warszawa: PWN, 2004.

Głodkowska Joanna, Być podmiotem i stawać się autorem swojego życia - paradygmat wsparcia $w$ przygotowaniu osób z niepetnosprawnościa do budowania własnej tożsamości i wzbogacania dobrostanu, „Człowiek - Niepełnosprawność - Społeczeństwo” 2014, nr 4.

Gortat Grzegorz, Szczury i wilki, Warszawa: Nasza Księgarnia, 2009.

Gosk Hanna, Bohater literacki o cechach Innego/Obcego, [w:] Hanna Gosk, Bohater swoich czasów. Postać literacka w powojennej prozie polskiej o tematyce wspótczesnej. Wybrane zagadnienia, Izabelin: Świat Literacki, 2002.

Grętkiewicz Ewa, Szczekająca szczęka Saszy, Warszawa: Nasza Księgarnia, 2005.

Gruchlik Honorata, Inność a obcość w kontekście filozoficznym, „Anthropos?” 2007, nr 8/9, http:// www.anthropos.us.edu.pl/anthropos5/texty/gruchlik.htm (dostęp: 22.10.2015).

Kapuściński Ryszard, Spotkanie z Innym jako wyzwanie XXI wieku, [w:] idem, Ten Inny, Kraków: Znak, 2006.

—, Wykłady wiedeńskie I, [w:] idem, Ten Inny, Kraków: Znak, 2006.

—, Wykłady wiedeńskie III, [w: ] idem, Ten Inny, Kraków: Znak, 2006.

Landau Irena, Uszy do góry!, Łódź: Wydawnictwo Literatura, 2011.

Nowak Ewa, Dane wrażliwe, Warszawa: Egmont, 2011.

Onichimowska Anna, Dziesięć stron świata, Kraków: Znak, 2007.

Pranić Katarzyna, Ela-Sanela, Warszawa: Stentor, 2011.

Ryrych Katarzyna, Wyspa mojej siostry, Warszawa: Stentor, 2011.

Sawicka Olga, Łukasińska Daria, Oro, Warszawa: Marginesy, 2012.

Sztachelska Jolanta, „Dziwność” dziecka. Rzecz o imaginarium spotecznym, [w:] Children studies jako perspektywa interpretacyjna. Studia i szkice, red. Jolanta Sztachelska, Karolina Szymborska, Białystok: Uniwersytet w Białymstoku, 2014. 
Środa Magdalena, Mała książka o tolerancji, Warszawa: Czarna Owca, 2010.

Tłuściak-Deliowska Aleksandra, Dystans społeczny wobec innych: analiza postaw młodzieży wobec wybranych grup narodowo-etnicznych, „Człowiek - Niepełnosprawność - Społeczeństwo” 2014, $\mathrm{nr} 4$.

Wróblewska Beata, Jabtko Apolejki, Warszawa: Stentor, 2007.

Xie Shaobo, Rethinking the Identity of Cultural Otherness: The Discourse of Difference as an Unfinished Project, [w:] Voices of the Other: Children's Literature and the Postcolonial Context, ed. Roderick McGillis, New York: Garland, 1999. 